\title{
Synthesis of ethynylated biaryls and asymmetric diethynylated benzene via sequential Sonogashira and Suzuki couplings in water
}

\author{
Hamdi M. Hassaneen, ${ }^{a}$ Kamal M. Dawood, ${ }^{*, a, b}$ Mohamed S. M. Ahmed, ${ }^{a}$ \\ Hyam A. Abdelhadi, ${ }^{a}$ and Mohamed A.-M. Mohamed ${ }^{a}$ \\ ${ }^{a}$ Chemistry Department, Faculty of Science, Cairo University, Giza 12613, Egypt \\ ${ }^{b}$ Current address: Department of Chemistry, Faculty of Science, Kuwait University, PO Box \\ 5969, Safat 13060, Kuwait \\ E-mail: $\underline{\text { drdawood@yahoo.com }}$
}

DOI: http://dx.doi.org/10.3998/ark.5550190.p009.123

\begin{abstract}
Two 1-bromo-4-ethynylbenzene candidates were synthesized from 1-bromo-4-iodobenzene via Sonogashira coupling then sequentially employed in Suzuki coupling with arylboronic acids in water to give ethynylated biaryl derivatives. Optimization of the reaction condition was done using two different palladium sources and various bases/solvents systems. Further sequential Sonogashira coupling of 1-bromo-4-ethynylbenzene candidates, in aqueous medium, afforded asymmetric diethynylated benzene derivatives.
\end{abstract}

Keywords: arylacetylenes, cross-coupling, catalysis, palladium, aqueous medium

\section{Introduction}

Palladium-catalyzed Sonogashira cross-coupling reaction of aryl halides with terminal alkynes is one of the most important reactions for synthesis of disubstituted alkynes. ${ }^{1,2}$ Unsymmetrical diarylethynes, as structural motifs with carbon-carbon triple bonds, have been developed in many synthetic transformations, pharmaceutical chemistry, natural products, and organic functional materials. ${ }^{3-8}$ In addition, Suzuki-Miyaura cross-coupling reaction is one of the most versatile and utilized reactions for carbon-carbon bond formation in the synthesis of natural products and pharmaceuticals. ${ }^{9-13}$ Water as an available, cheap, renewable, safe and green solvent and allows easy work up and separation, has been exploited in several catalytic $\mathrm{C}-\mathrm{C}$ bond formation reactions and was reported as an important partner in improving the catalyst activity. ${ }^{14-}$ ${ }^{18}$ In continuation of our research work on C-C cross-coupling reactions catalyzed by $\mathrm{Pd}(\mathrm{II})-$ complexes in water, ${ }^{19-29}$ we envisioned here that the 1-bromo-4-iodobenzene represents a suitable candidate for sequential Sonogashira and Suzuki cross-coupling for synthesis of new 
ethynylated biaryls and asymmetric diethynylated benzene derivatives using either the benzothiazole-oxime $\mathrm{Pd}(\mathrm{II})$-complex I or the commercially available $\mathrm{PdCl}_{2}\left(\mathrm{PPh}_{3}\right)_{2}$ II in aqueous medium.

\section{Results and Discussion}

The first task was to synthesize 1-bromo-4-(2-phenylethynyl)benzene (4) and 1-bromo-4-(1octynyl)benzene (5), via Sonogashira coupling of 1-bromo-4-iodobenzene (3) with phenylacetylene (1) or 1-octyne (2), to serve as substrates for achieving the objectives. The coupling was conducted in aqueous conditions at room temperature following a recently reported procedure for analogous examples. ${ }^{29}$ Thus, reaction of equimolar amounts of 1-bromo-4iodobenzene (3) with phenylacetylene (1) or 1-octyne (2) at room temperature using $\mathrm{PdCl}_{2}\left(\mathrm{PPh}_{3}\right)_{2}$ (cat. II) $(1 \mathrm{~mol} \%)$ and $\mathrm{CuI}(2 \mathrm{~mol} \%)$ in toluene/water mixed solvent $(1 / 1, \mathrm{v} / \mathrm{v})$ in the presence of triethylamine under argon furnished the corresponding 1-bromo-4ethynylbenzene derivatives 4 and 5 in 98\% and 96\% isolated yields, respectively (Scheme 1).

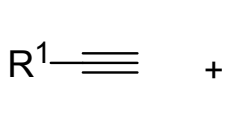

1,2

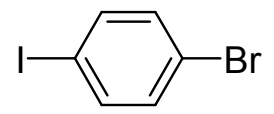

3

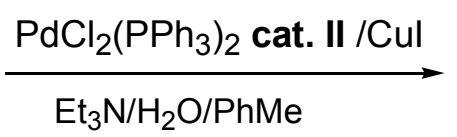

Argon, rt, 8 12 h

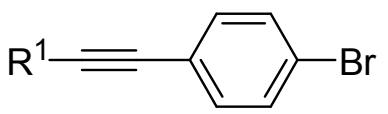

$4,5 \quad 96 \sim 98 \%$

1,4: $\mathrm{R}^{1}=\mathrm{C}_{6} \mathrm{H}_{5}$

2,5: $\mathrm{R}^{1}={ }^{n} \mathrm{C}_{6} \mathrm{H}_{13}$

Scheme 1. Synthesis of 1-bromo-4-ethynylbenzene derivatives 4 and 5

From a survey of the literature, it was found that very few examples of Suzuki cross-coupling of 1-bromo-4-ethynylbenzene derivatives $\mathbf{4}$ and $\mathbf{5}$ were reported. ${ }^{30-32}$ Therefore, we first concerned on evaluation of the catalytic activity of the Pd-precatalysts I and II in the SuzukiMiyaura cross-coupling reaction of 1-bromo-4-(2-phenylethynyl)benzene (4) with phenylboronic acid (6a) under different catalytic conditions (e.g. concentration of catalyst, bases and solvents). At first, the reaction was carried out using Pd-oxime-complex (cat. I) in different solvents (water and toluene) at reflux temperature using a variety of bases and the results are outlined in Table 1. Tetrabutylammonium bromide (TBAB) was used in 0.6 equiv for water solvent. Using $\mathrm{NaOH} / \mathrm{TBAB} /$ water as catalytic system in the presence of $1 \mathrm{~mol} \%$ Pd-cat $\mathbf{I}$ at reflux temperature for $8 \mathrm{hr}$ gave only $50 \%$ yield and the starting material did not completely consume (Table 1, run 1). Repeating the same conditions using $2 \mathrm{~mol} \%$ of the Pd-cat I resulted in full conversion into the cross-coupled product 1-phenyl-2-(4-biphenylyl)acetylene (7) in 85\% isolated yield (Table 1, run 2). Under the typical conditions above, when water was replaced with toluene at reflux for 4 hr, the product 6 was obtained in 73\% yield (Table 1, run 3). Using $\mathrm{K}_{2} \mathrm{CO}_{3} / \mathrm{TBAB} /$ water and 2 mol\% Pd-cat I at reflux yielded $88 \%$ yield of 7 (Table 1, run 4). 
Next, the coupling reaction was carried out using bis(triphenylphosphine)palladium(II) dichloride; $\mathrm{PdCl}_{2}\left(\mathrm{PPh}_{3}\right)_{2}$ (cat II) in water or toluene at $60{ }^{\circ} \mathrm{C}$ using $\mathrm{K}_{2} \mathrm{CO}_{3}$ or $\mathrm{Et}_{3} \mathrm{~N}$ as bases and as shown in Table 1, runs 5-8. Conducting Suzuki coupling using $\mathrm{Et}_{3} \mathrm{~N} / \mathrm{H}_{2} \mathrm{O} / \mathrm{TBAB}$ system in the presence of $1 \mathrm{~mol} \%$ of cat II gave better result (93\% yield) of 7 if compared with the catalytic system $\mathrm{K}_{2} \mathrm{CO}_{3} / \mathrm{H}_{2} \mathrm{O} / \mathrm{TBAB}$ (70\% yield) under the same conditions (Table 1, runs 5, 7). Toluene was not suitable solvent either in the presence of $\mathrm{Et}_{3} \mathrm{~N}$ or $\mathrm{K}_{2} \mathrm{CO}_{3}$ where the products yields were $20 \%$ and $30 \%$, respectively (Table 1 , runs 6 and 8 ). The obtained product was identical with that reported from Sonogashira coupling of phenylacetylene with 4-bromobiphenyl. ${ }^{33}$

Table 1. Suzuki coupling of 1-bromo-4-(2-phenylethynyl)benzene (4) with phenylboronic acid (6a)
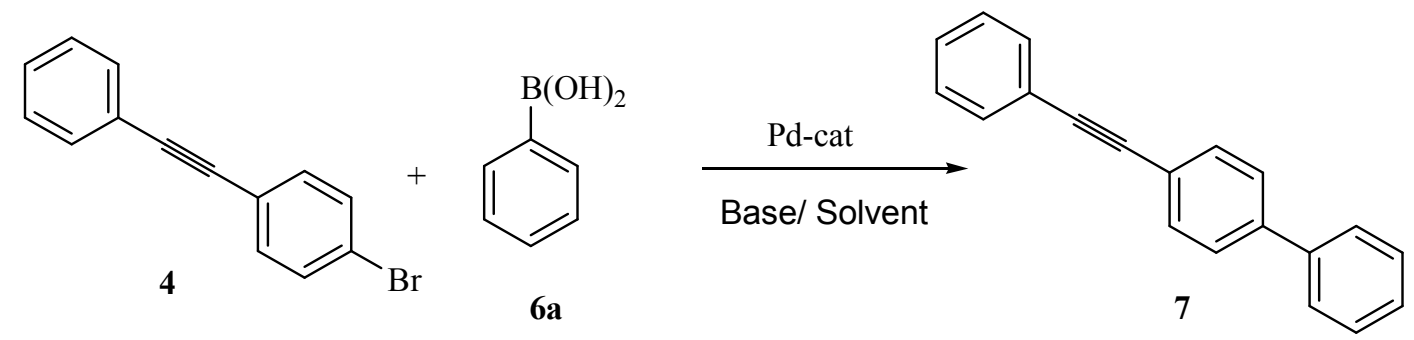

\begin{tabular}{ccccccc}
\hline Run & Pd-cat. (mol\%) & Base & Solvent & Temp. ${ }^{\circ} \mathrm{C}$ & Time hr & Yield \% ${ }^{\mathrm{a}}$ \\
\hline 1 & Pd-cat I (1) & $\mathrm{NaOH}$ & $\mathrm{H}_{2} \mathrm{O}$ & 100 & 8 & 50 \\
2 & Pd-cat I (2) & $\mathrm{NaOH}$ & $\mathrm{H}_{2} \mathrm{O}$ & 100 & 4 & 85 \\
3 & Pd-cat I (2) & $\mathrm{NaOH}$ & Toluene & 100 & 4 & 73 \\
4 & Pd-cat I (2) & $\mathrm{K}_{2} \mathrm{CO}_{3}$ & $\mathrm{H}_{2} \mathrm{O}$ & 100 & 4 & 88 \\
5 & Pd-cat II (1) & $\mathrm{Et}_{3} \mathrm{~N}$ & $\mathrm{H}_{2} \mathrm{O}$ & 60 & 2 & 93 \\
6 & Pd-cat II (1) & $\mathrm{Et}_{3} \mathrm{~N}$ & Toluene & 60 & 2 & 20 \\
7 & Pd-cat II (1) & $\mathrm{K}_{2} \mathrm{CO}_{3}$ & $\mathrm{H}_{2} \mathrm{O}$ & 60 & 2 & 72 \\
8 & Pd-cat II (1) & $\mathrm{K}_{2} \mathrm{CO}_{3}$ & Toluene & 60 & 2 & 30 \\
\hline
\end{tabular}

${ }^{a}$ Conditions: Bromide 4/Boronic acid 6a/Base/TBAB/Solvent (ml): 1:1.5:2:0.6:2, thermal heating.

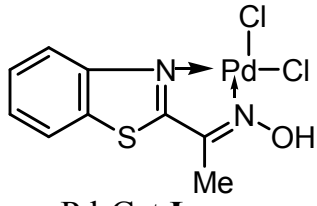

Pd-Cat I
$\mathrm{PdCl}_{2}\left(\mathrm{PPh}_{3}\right)_{2}$

Pd-Cat II

When Suzuki coupling of the 1-bromo-4-(2-phenylethynyl)benzene (4) with 3chlorophenylboronic acid (6b) was similarly carried out in $\mathrm{H}_{2} \mathrm{O} / \mathrm{K}_{2} \mathrm{CO}_{3} / \mathrm{TBAB}$ reaction system under thermal heating at $100{ }^{\circ} \mathrm{C}$ using $1 \mathrm{~mol} \%$ Pd-cat. I (Table 2, run 1) or at $60{ }^{\circ} \mathrm{C}$ using 1 
mol\% Pd-cat II (Table 2, run 2), it resulted in the formation of 1-(3-chlorophenyl)-2-(4biphenylyl)acetylene (8) in excellent isolated yields.

Likewise, 2-(4-biphenylyl)-1-(4-tolyl)acetylene (9) was synthesized via Suzuki coupling of 1-bromo-4-(2-phenylethynyl)benzene 4 with 4-tolylboronic acid $\mathbf{6 c}$ in $\mathrm{H}_{2} \mathrm{O} / \mathrm{K}_{2} \mathrm{CO}_{3} / \mathrm{TBAB}$ using $1 \mathrm{~mol} \%$ of Pd-catalysts I and II as described in Table 2, runs 3,4. 2-(4-Biphenylyl)-1-(4tolyl)acetylene (9) was obtained in 60\% yield after 24 hours at reflux (using Pd-cat I) and in 92\% yield after $2 \mathrm{hr}$ at $60{ }^{\circ} \mathrm{C}$ (using Pd-cat II), respectively. Product 9 was alternatively synthesized in literature by Sonogashira coupling of 4-bromophenyltrifluoroborate with phenylacetylene using $\mathrm{Pd}\left(\mathrm{PPh}_{3}\right)_{4} / \mathrm{CuI}$ catalyst in DMSO- $d_{6}$ followed by Suzuki coupling of the product with 4bromotoluene. ${ }^{34}$

Pd-catalyst $I$ was found to be less efficient (Table 2, run 5) in water/TBAB/ $\mathrm{K}_{2} \mathrm{CO}_{3}$ after heating the coupling partners 4 and $\mathbf{6 d}$ for $24 \mathrm{hr}$ at reflux, where 2-(4-biphenylyl)-1-(3anisyl)acetylene (10) was obtained in $70 \%$ yield and the starting material did not completely consume as detected by TLC. In contrast, when $\mathrm{PdCl}_{2}\left(\mathrm{PPh}_{3}\right)_{2}$ II was employed at $60{ }^{\circ} \mathrm{C}$, the cross-coupling partners $\mathbf{4}$ and $\mathbf{6 d}$ were completely consumed after $2 \mathrm{hr}$ with full conversion into the coupling product 10 and 95\% isolated yield (Table 2, run 6). Structure of 2-(4-biphenylyl)-1(3-anisyl)acetylene (10) was elucidated by ${ }^{1} \mathrm{H}$ and ${ }^{13} \mathrm{C}$ NMR and IR spectroscopy. The ${ }^{1} \mathrm{H}$ NMR spectrum of 10 revealed characteristic singlet signal at $\delta 3.87$ due to methoxy protons in addition to the aromatic protons and its ${ }^{13} \mathrm{C}$ NMR spectrum showed 17 carbon signals and the IR spectrum showed a peak at $2206 \mathrm{~cm}^{-1}$ corresponding to the acetylene moiety.

The Suzuki coupling reaction of 1-bromo-4-(2-phenylethynyl)benzene (4) with 3thienylboronic acid (6e) was similarly carried out under thermal heating in water as shown in Table 2, runs 7, 8. Using $1 \mathrm{~mol} \%$ Pd-complex $\mathbf{I}$ in water/TBAB/ $\mathrm{K}_{2} \mathrm{CO}_{3}$, a poor yield (35\%) of 2(4-biphenylyl)-1-(3-thienyl)acetylene (11) was obtained after $24 \mathrm{hr}$ of reflux. The use of $\mathrm{PdCl}_{2}\left(\mathrm{PPh}_{3}\right)_{2}$ (cat. II) $(1 \mathrm{~mol} \%)$ at $60{ }^{\circ} \mathrm{C}$ for 24 hours gave $89 \%$ yield of the coupled product 11 (Table 2, run 8).

The alkyne moiety is a $\pi$-electron donating group and consequently the aryl bromide 4 is considered as deactivated bromide. This may be a reason for, in some cases, the low conversion yields when our previously reported ${ }^{22} \mathrm{Pd}$-catalyst I was employed in the catalytic system comparing to the more reactive catalyst $\mathrm{PdCl}_{2}\left(\mathrm{PPh}_{3}\right)_{2}$. 
Table 2. Suzuki coupling of 1-bromo-4-(2-phenylethynyl)benzene 4 with arylboronic acids $\mathbf{6 b - e}$<smiles>Brc1ccc(C#Cc2ccccc2)cc1</smiles>

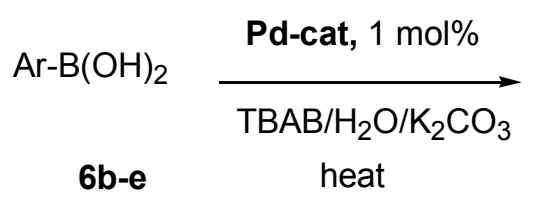<smiles>Brc1ccc(C#Cc2ccccc2)cc1</smiles>

\begin{tabular}{|c|c|c|c|c|c|c|c|}
\hline Run & $\operatorname{ArB}(\mathrm{OH})_{2}$ & Ar & Product & $\begin{array}{c}\mathrm{Pd} \\
\text { catalyst }\end{array}$ & $\begin{array}{c}\text { Temp. } \\
{ }^{\circ} \mathrm{C}\end{array}$ & Time hr & Yield $\%{ }^{\mathrm{a}}$ \\
\hline 1 & $6 b$ & & 8 & cat. I & 100 & 3 & 96 \\
\hline 2 & $6 b$ & $\mathrm{Cl}$ & 8 & cat. II & 60 & 5 & 93 \\
\hline 3 & $6 c$ & & 9 & cat. I & 100 & 24 & 61 \\
\hline 4 & $6 c$ & & 9 & cat. II & 60 & 2 & 92 \\
\hline 5 & 6d & & 10 & cat. I & 100 & 24 & 70 \\
\hline 6 & 6d & & 10 & cat. II & 60 & 2 & 95 \\
\hline 7 & $6 e$ & & 11 & cat. I & 100 & 24 & 35 \\
\hline 8 & $6 e$ & & 11 & cat. II & 60 & 24 & 89 \\
\hline
\end{tabular}

${ }^{a}$ Conditions: Bromide/Boronic acid/Base/TBAB/water (ml): 1:1.5:2:0.6 :2, thermal heating. 
Next, Suzuki coupling reaction of 1-bromo-4-(1-octynyl)benzene (5) with phenylboronic acid (6a) was conducted in water as green solvent in the presence of $1 \mathrm{~mol} \%$ of the Pdprecatalysts I or II to afford 1-(4-biphenylyl)-1-octyne $\mathbf{1 2}$ as outlined in Table 3. The crosscoupling reactions using Pd-catalyst I (at $100{ }^{\circ} \mathrm{C}$ ) or Pd-catalyst II (at $60{ }^{\circ} \mathrm{C}$ ) in water/TBAB $/ \mathrm{K}_{2} \mathrm{CO}_{3}$ led to the formation of 12 in $92 \%$ and $95 \%$ isolated yields, respectively (Table 3, runs 1,2). Alternatively, Zhao and his group $^{35}$ synthesized compound $\mathbf{1 2}$ by Sonogashira coupling of 4-iodobiphenyl with 1-octyne 2 in neat diethylamine using $\mathrm{PdCl}_{2}\left(\mathrm{PPh}_{3}\right)_{2}$ (cat. II) and $\mathrm{CuI}$ at room temperature.

Further, Suzuki coupling of 1-bromo-4-(1-octynyl)-benzene (5) and 3-chlorophenylboronic acid (6b) was similarly carried out in $\mathrm{H}_{2} \mathrm{O} / \mathrm{TBAB} / \mathrm{K}_{2} \mathrm{CO}_{3}$ using $1 \mathrm{~mol} \%$ of Pd-catalyst $\mathbf{I}$ (at 100 ${ }^{\circ} \mathrm{C}$ for $4 \mathrm{hr}$ ) and Pd-catalyst II (at $60{ }^{\circ} \mathrm{C}$ for $2 \mathrm{hr}$ ) gave 1-(3'-chloro-4-biphenylyl)-1-octyne (13) in $91 \%$ and $94 \%$ isolated yields, respectively (Table 3, runs 3, 4). In the same manner, Suzuki cross-coupling reactions of 1-bromo-4-(1-octynyl)benzene (5) with 4-tolylboronic acid (6c) and 4-anisylboronic acid (6d) were conducted in the catalytic system; $\mathrm{H}_{2} \mathrm{O} / \mathrm{TBAB} / \mathrm{K}_{2} \mathrm{CO}_{3}$ in the presence of $1 \mathrm{~mol} \%$ Pd-catalyst $\mathbf{I}$ at $100{ }^{\circ} \mathrm{C}$ for 24 hours and the starting material were not completely consumed, as tested by TLC, and the cross-coupled products 14 and 15 were obtained in $40 \%$ and $50 \%$ yields, respectively (Table 3, runs 5, 7). When Suzuki coupling reactions of 1-bromo-4-(1-octynyl)benzene (5) with 4-tolylboronic acid (6c) and 4-anisylboronic acid (6d) were repeated in the presence of $1 \mathrm{~mol} \%$ Pd-catalyst II at $60{ }^{\circ} \mathrm{C}$, the cross-coupled products 1-(4-(4'-tolyl)phenyl)-1-octyne (14) and 1-(4-(4'-anisyl)phenyl)-1-octyne (15) were obtained in $87 \%$ and $90 \%$ yields, respectively (Table 3 , run 6,8$)$.

Pd-complex I was found to be a poor catalyst for coupling of 1-bromo-4-(1-octynyl)benzene (5) with 3-thienylboronic acid (6e) in water/TBAB $/ \mathrm{K}_{2} \mathrm{CO}_{3}$ where the reaction did not complete even after $24 \mathrm{hr}$ heating at $100{ }^{\circ} \mathrm{C}$ (Table 3, run 9) and the cross-coupled product 1-(4-(3thienyl)phenyl)-1-octyne (16) was isolated in only $40 \%$ yield. The use of $1 \mathrm{~mol} \%$ of $\mathrm{PdCl}_{2}\left(\mathrm{PPh}_{3}\right)_{2}$ (cat. II) at $60{ }^{\circ} \mathrm{C}$ for $15 \mathrm{hr}$, however, resulted in full conversion of the starting bromide 5 into the cross-coupled product 16 in 90\% isolated yield (Table 3, run 10).

By controlling the reaction conditions, it was easy to introduce two different ethynyl groups into benzene ring starting with 1-bromo-4-iodobenzene (3). The 4-bromo-1-(oct-1-ynyl)benzene (5) was used further in a sequential Sonogashira cross-coupling with phenylacetylene 1 using $\mathrm{PdCl}_{2}\left(\mathrm{PPh}_{3}\right)_{2}$ (cat II) $(1 \mathrm{~mol} \%)$ in the presence of $\mathrm{CuI}(2 \mathrm{~mol} \%)$ and triethylamine (2 equiv) in water/toluene mixed solvent $(1: 1, \mathrm{v}: \mathrm{v})$ under argon atmosphere at $60^{\circ} \mathrm{C}$ for $24 \mathrm{~h}$, to give the new 1-(oct-1-ynyl)-4-(2-phenylethynyl)benzene (19) in 65\% isolated yield as shown in Scheme 2. Pd-complex (cat II) was found to be not appropriate catalyst for Sonogashira coupling of 4bromo-1-(oct-1-ynyl)benzene (5) with phenylacetylene 1, where conducting the reaction using 1 mol\% of cat II in toluene $/ \mathrm{H}_{2} \mathrm{O} / \mathrm{Et}_{3} \mathrm{~N}$ without $\mathrm{CuI}$ under argon atmosphere at $60^{\circ} \mathrm{C}$ for $24 \mathrm{~h}$ gave only $19 \%$ yield of compound 19 . 
Table 3. Suzuki coupling of 1-bromo-4-(1-octynyl)benzene (5) with arylboronic acid 6a-e

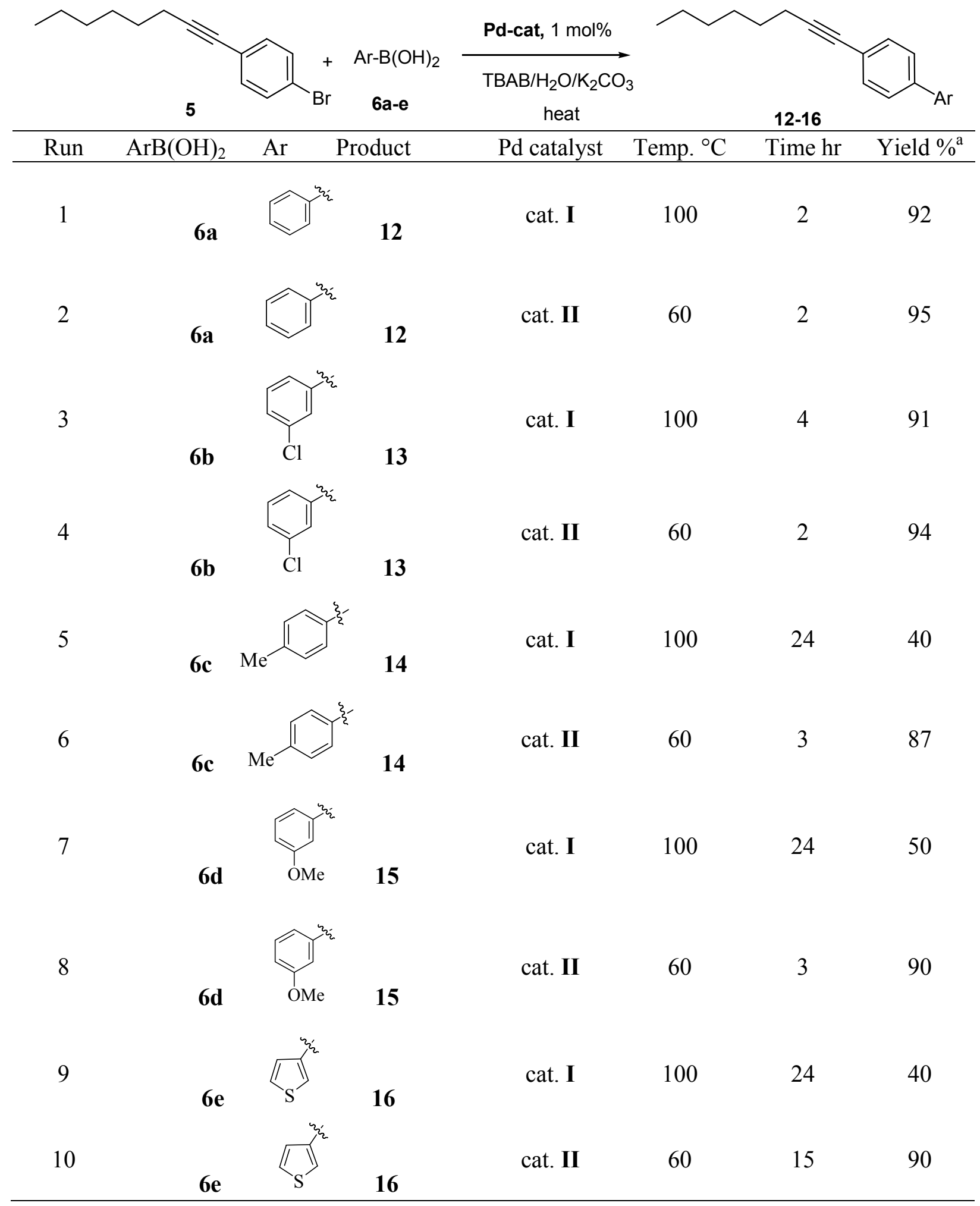

${ }^{a}$ Conditions: Bromide/Boronic acid/Base/TBAB/water (ml): 1:1.5:2:0.6:2, thermal heating. 
By the same strategy, the asymmetric diethynylated benzene derivative; 1-(4hexyloxyphenylethynyl)-4-(1-octynyl)benzene (20) could be synthesized. Thus, cross-coupling reaction of 4-bromo-1-(oct-1-ynyl)benzene (5) with 4-hexyloxyphenylacetylene (17) using $\mathrm{PdCl}_{2}\left(\mathrm{PPh}_{3}\right)_{2}$ (cat II) $(1 \mathrm{~mol} \%)$ in the presence of $\mathrm{CuI}(2 \mathrm{~mol} \%)$ in toluene $/ \mathrm{H}_{2} \mathrm{O} / \mathrm{Et}_{3} \mathrm{~N}$ under argon atmosphere at $60^{\circ} \mathrm{C}$ for $24 \mathrm{~h}$ yielded 20 in $90 \%$ isolated yield. It is worthy to note that, the asymmetric diethynylbenzene derivative $\mathbf{2 0}$ could be synthesized alternatively in excellent yield (98\%) through coupling of 1-octyne 2 with 4-bromo-1-(4-hexyloxyphenylethynyl)benzene (18) using $\mathrm{PdCl}_{2}\left(\mathrm{PPh}_{3}\right)_{2}$ in the presence of $\mathrm{CuI}$ in toluene/water mixed solvent and triethylamine as a base under argon atmosphere at $60^{\circ} \mathrm{C}$ for $24 \mathrm{~h}$ (Scheme 2). The reaction molar ratios were typically; $1 \mathrm{mmol}$ alkyne 2, $1 \mathrm{mmol}$ bromide 18, 2 mmoles $\mathrm{Et}_{3} \mathrm{~N}, 1 \mathrm{~mol} \% \mathrm{PdCl}_{2}\left(\mathrm{PPh}_{3}\right)_{2}$ and 2 $\mathrm{mol} \% \mathrm{CuI}$ in water/toluene ( $2 \mathrm{ml}, 1: 1 \mathrm{v} / \mathrm{v})$.

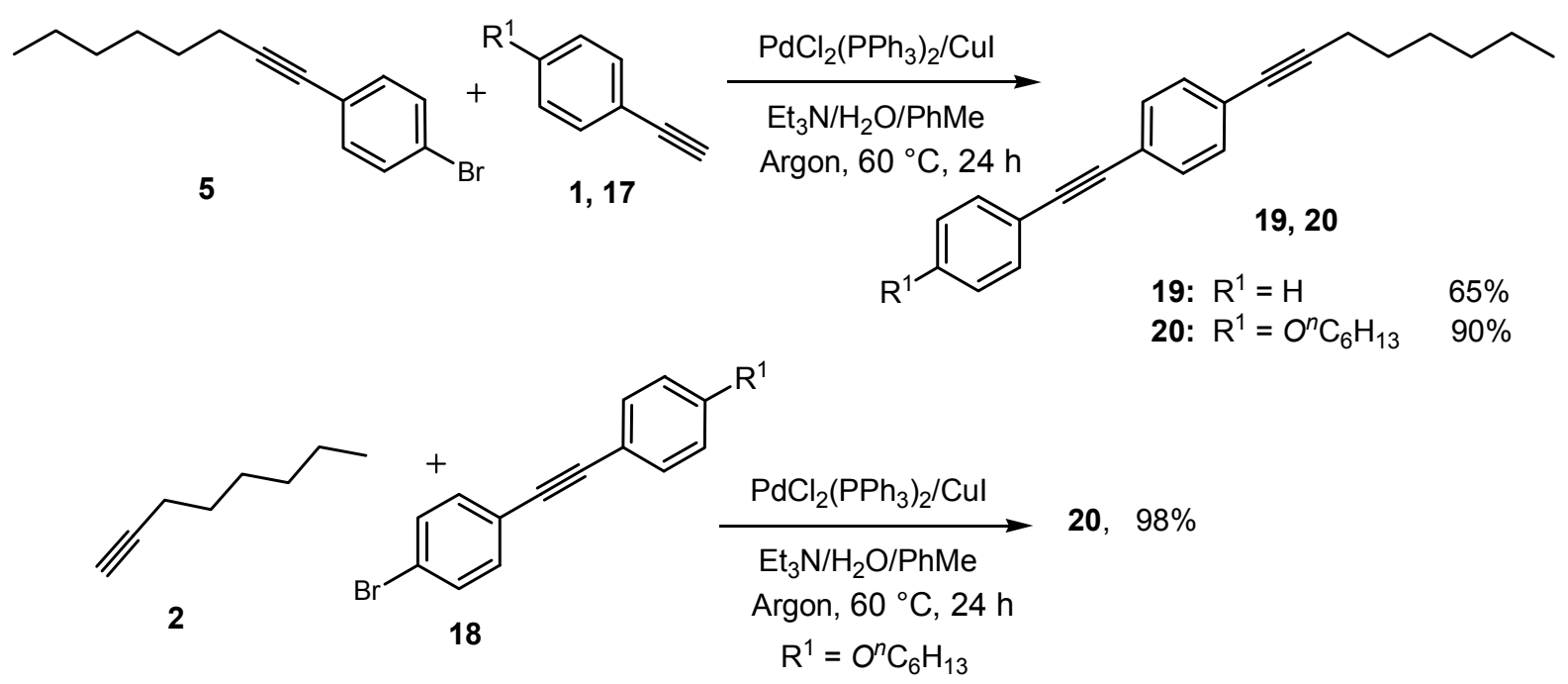

Scheme 2. Synthesis of asymmetric diethynylated benzene derivatives $\mathbf{1 9}$ and $\mathbf{2 0}$

\section{Conclusions}

We have developed an effective and convenient protocol for the palladium(II)-catalyzed ligandfree synthesis of 4-ethynylated biaryl derivatives via sequential Sonogashira then Suzuki crosscoupling reaction in water in the presence of $\mathrm{K}_{2} \mathrm{CO}_{3}$ in open air. Also, sequential Sonogashira cross-coupling 1-bromo-4-iodobenzene different ethynylated benzene derivatives using ligandfree $\operatorname{Pd}(\mathrm{II})$-catalyst, in aqueous medium under argon atmosphere, led to the formation of the asymmetric 1,4-diethynylated benzene derivatives. 


\section{Experimental section}

General: Melting points were measured in open glass capillaries with a Gallenkamp apparatus. The infrared spectra were recorded in potassium bromide disks on a Pye Unicam SP 3-300 and Shimaduz FTIR 8101 PC infrared spectrophotometer. NMR spectra were recorded with a Varian Mercury VXR-300 NMR spectrometer at $300 \mathrm{MHz}\left({ }^{1} \mathrm{H} \mathrm{NMR}\right)$ and at $75 \mathrm{MHz}\left({ }^{13} \mathrm{C} \mathrm{NMR}\right)$ at Cairo University or on a Jeol LA $400 \mathrm{MHz}\left(400 \mathrm{MHz}\right.$ for ${ }^{1} \mathrm{H}, 100 \mathrm{MHz}$ for the $\left.{ }^{13} \mathrm{C}\right)$ at Assiut University, using $\mathrm{CDCl}_{3}$ as solvent and internal standard $\left(\delta 7.27\right.$ and $77.36 \mathrm{ppm}$, for ${ }^{1} \mathrm{H}$ NMR and ${ }^{13} \mathrm{C}$ NMR, respectively). Chemical shifts $(\delta)$ and $J$ values are reported in ppm and $\mathrm{Hz}$, respectively. Electrospray ionization mass spectrometry (EI-MS) analyses were obtained at 70 eV with a type Shimadzu GCMQP 1000 EX spectrometer. Analytical thin-layer chromatography (TLC) was conducted using pre-coated silica gel 60778 plates (Fluka), and the spots were visualized with UV light at $254 \mathrm{~nm}$. Fluka silica gel 60741 (70-230 mesh) was used for flash column chromatography. For the elimination of atmospheric oxygen from the reaction medium, the aqueous solvent was firstly deoxygenated with a stream of argon for 30 min before use. Synthesis of the Pd(II)-complex (Pd-cat I) ${ }^{22}$ and 4-hexyloxyphenylacetylene $17^{29,36}$ were prepared following the procedures reported in literature.

\section{Preparation of 1-bromo-4-ethynylbenzene derivatives 4 and 5}

To $\mathrm{PdCl}_{2}\left(\mathrm{PPh}_{3}\right)_{2}$ II (7 mg, $\left.0.01 \mathrm{mmol}\right)$, CuI (3.8 mg, $\left.0.02 \mathrm{mmol}\right)$, and 1-bromo-4-iodobenzene 3 $(283 \mathrm{mg}, 1 \mathrm{mmol})$ in toluene $(1 \mathrm{~mL})$ and $\mathrm{Et}_{3} \mathrm{~N}(280 \mu \mathrm{L}, 2 \mathrm{mmoles})$ in water $(1 \mathrm{~mL})$, was added phenylacetylene 1 or 1-octyne 2 (1 mmol) under an argon atmosphere, and stirring was continued at room temperature for $18 \mathrm{hr}$. Then the mixture was diluted with $20 \mathrm{~mL}$ of diethyl ether and then passed through a Celite pad to remove any insoluble solid residue, which was washed with $20 \mathrm{~mL}$ of diethyl ether. The combined filtrate was evaporated under reduced pressure to leave a crude product, which was subjected to flash column chromatography on silica gel (hexane-ethyl acetate) (100:1) to furnish of the cross-coupled products $\mathbf{4}$ and $\mathbf{5}$, respectively.

1-Bromo-4-(2-phenylethynyl)benzene (4): ${ }^{37}$ White powder, yield $98 \%$; mp. 80-81 ${ }^{\circ} \mathrm{C} ;{ }^{1} \mathrm{H}$ NMR $\left(\mathrm{CDCl}_{3}\right) \delta$ 7.35-7.42 (m, 5H, ArH), 7.48-7.56 (m, 4H, ArH).

4-Bromo-1-(oct-1-ynyl)benzene (5): ${ }^{38}$ Yellow oil; ${ }^{1} \mathrm{H}$ NMR $\left(\mathrm{CDCl}_{3}\right) \delta 0.93(\mathrm{t}, 3 \mathrm{H}, J=6.6 \mathrm{~Hz})$, $1.28-1.63(\mathrm{~m}, 8 \mathrm{H}), 2.39$ (t, 2H, $J=7.2 \mathrm{~Hz}), 7.25$ (d, 2H, $J=8.7 \mathrm{~Hz}), 7.42$ (d, 2H, $J=8.7 \mathrm{~Hz})$.

\section{Effect of base and solvent on Suzuki coupling of 1-bromo-4-(phenylethynyl)benzene (4) with phenylboronic acid 6 a using palladium catalyst $I$}

A mixture of 1-bromo-4-(2-phenylethynyl)benzene (4) (257 mg, $1 \mathrm{mmol})$, phenylboronic acid 6a (183 mg, $1.5 \mathrm{mmol})$, TBAB (194 mg, $0.6 \mathrm{mmol})$, palladium catalyst I (7.4 mg, $2 \mathrm{~mol} \%)$ and the appropriate base $(2 \mathrm{mmol})$ in water or toluene $(2 \mathrm{~mL})$ was heated at $100{ }^{\circ} \mathrm{C}$ with stirring under open air. The cross-coupled product, in each time, was then extracted with diethyl ether $(3 \times 30$ $\mathrm{mL}$ ). The combined organic extracts were dried over anhydrous $\mathrm{MgSO}_{4}$ then filtered and the 
solvent was evaporated under reduced pressure. The residue was then purified via column chromatography with hexane-ethyl acetate as an eluent to give the cross-coupled product 7.

Effect of base and solvent on Suzuki coupling of 1-bromo-4-(phenylethynyl)benzene (4) with phenylboronic acid 6 a using palladium catalyst II

A mixture of 1-bromo-4-(2-phenylethynyl)benzene (4) (257 mg, $1 \mathrm{mmol})$, phenylboronic acid 6a (183 mg, $1.5 \mathrm{mmol})$, TBAB (194 mg, $0.6 \mathrm{mmol})$, palladium catalyst II (7 mg, $1 \mathrm{~mol} \%)$ and the appropriate base $(2 \mathrm{mmol})$ in degassed solvent: water or toluene $(2 \mathrm{~mL})$ was heated at $60{ }^{\circ} \mathrm{C}$ with stirring under argon atmosphere. The cross-coupled product, in each time, was then extracted with diethyl ether $(3 \times 30 \mathrm{~mL})$. The combined organic extracts were dried over anhydrous $\mathrm{MgSO}_{4}$ then filtered and the solvent was evaporated under reduced pressure. The residue was then purified via column chromatography with hexane-ethyl acetate as an eluent to give the crosscoupled product 7 .

Suzuki cross-coupling of 1-bromo-4-ethynylbenzene derivatives 4 and 5 with arylboronic acids 6a-e using Pd-catalyst I. General procedure

A mixture of 1-bromo-4-(phenylethynyl)benzene (4) or 1-bromo-4-(oct-1-ynyl)benzene (5) (1 $\mathrm{mmol})$, and the appropriate arylboronic acid 6a-e $(1.5 \mathrm{mmol})$, TBAB (194 mg, $0.6 \mathrm{mmol})$, palladium catalyst I (7.4 mg, $2 \mathrm{~mol} \%), \mathrm{K}_{2} \mathrm{CO}_{3}(276 \mathrm{mg}, 2 \mathrm{mmol})$, and water $(2 \mathrm{~mL})$ was shaken at $100{ }^{\circ} \mathrm{C}$ under open air. After the reaction was almost complete (monitored by TLC), the reaction mixture was left to cool to room temperature. The products were then extracted three times with diethyl ether $(3 \times 30 \mathrm{ml})$ and then the organic fractions were combined together, dried over $\mathrm{MgSO}_{4}$, filtered, and then the solvent was removed under vacuum. The residue was then purified via column chromatography with hexane-ethyl acetate as an eluent to give the corresponding cross-coupled products 7-11 and 12-16, respectively.

\section{Suzuki cross-coupling of 1-bromo-4-ethynylbenzene derivatives 4 and 5 with arylboronic acids 6a-e using $\mathbf{P d C l}_{2}\left(\mathbf{P P h}_{3}\right)_{2}$ II. General procedure}

To a mixture 1-bromo-4-(phenylethynyl)benzene (4) or 1-bromo-4-(oct-1-ynyl)benzene (5) (1 mmol) and $\mathrm{PdCl}_{2}\left(\mathrm{PPh}_{3}\right)_{2}$ (cat. II) $(7 \mathrm{mg}, 0.01 \mathrm{mmol})$ in degassed water $(2 \mathrm{~mL})$, was added the appropriate arylboronic acid 6a-e $(1.5 \mathrm{mmol})$ with stirring under an argon atmosphere. After that, $\mathrm{K}_{2} \mathrm{CO}_{3}(276 \mathrm{mg}, 2 \mathrm{mmol})$ was added and the mixture was left to stir at $60{ }^{\circ} \mathrm{C}$ till the reaction was almost complete (monitored by TLC). After cooling, the resulting mixture was extracted with diethyl ether $(3 \times 30 \mathrm{~mL})$. The organic fractions were combined together, dried over $\mathrm{MgSO}_{4}$, filtered, and then the solvent was removed under vacuum to leave a crude solid, which was purified by chromatography on silica gel with hexane-ethyl acetate to furnish the corresponding coupling products 7-11 and 12-16, respectively.

4-(2-Phenylethynyl)biphenyl (7): Off-white solid, mp 160-161 ${ }^{\circ} \mathrm{C}$ (Lit. ${ }^{33} \mathrm{mp} .162-163{ }^{\circ} \mathrm{C}$ ); IR $\left(v_{\max }, \mathrm{cm}^{-1}\right): 3034,2219,1482 .{ }^{1} \mathrm{H}$ NMR $\left(400 \mathrm{MHz}, \mathrm{CDCl}_{3}\right): \delta_{\mathrm{H}} 7.31-7.38\left(4 \mathrm{H}_{\text {arom }}, \mathrm{m}, 4 \mathrm{CH}\right)$, 
7.43-7.47 $\left(2 \mathrm{H}_{\text {arom }}, \mathrm{m}, 2 \mathrm{CH}\right), 7.51-7.62\left(8 \mathrm{H}_{\text {arom }}, \mathrm{m}, 8 \mathrm{CH}\right)$; MS (EI, $\left.70 \mathrm{eV}\right): \mathrm{m} / z(\%)=254\left(\mathrm{M}^{+}\right.$, 100), 250 (7.2), 127 (17.6), 113 (8.3), 80 (14.9), 64 (8.7).

3'-Chloro-4-(phenylethynyl)biphenyl (8): Off-white solid, mp 117-118 ${ }^{\circ} \mathrm{C}$; IR $\left(v_{\max }, \mathrm{cm}^{-1}\right)$ : 3057, 2325, 1468. ${ }^{1} \mathrm{H}$ NMR $\left(400 \mathrm{MHz}, \mathrm{CDCl}_{3}\right): \delta_{\mathrm{H}} 7.32-7.38\left(5 \mathrm{H}_{\text {arom }}, \mathrm{m}, 5 \mathrm{CH}\right), 7.47\left(1 \mathrm{H}_{\text {arom }}, \mathrm{d}\right.$, $\left.{ }^{3} J_{\mathrm{HH}} 8.7 \mathrm{~Hz}, 1 \mathrm{H}\right), 7.50-7.65\left(7 \mathrm{H}_{\text {arom }}, \mathrm{m}, 7 \mathrm{CH}\right) ;{ }^{13} \mathrm{C} \mathrm{NMR}\left(100 \mathrm{MHz}, \mathrm{CDCl}_{3}\right): \delta_{\mathrm{C}} 89.0,90.4$, $122.8,123.1,125.1,126.9,127.1,127.6,128.4,130.1,131.6,132.1,134.7,139.4,142.1$; MS (EI, $70 \mathrm{eV}): m / z(\%)=290\left(\mathrm{M}^{+}+2,35\right), 289\left(\mathrm{M}^{+}+1,22.7\right), 288\left(\mathrm{M}^{+}, 100\right), 252(27.9), 250(15.7), 144$ (14.8), 126 (21.3), 113 (16.9), 100 (6.9), 80 (15.9), 64 (9.7). Anal. Calcd for $\mathrm{C}_{20} \mathrm{H}_{13} \mathrm{Cl}$ (288.77): C, 83.19; H, 4.54\%. Found: C, 83.55; H, 4.61\%.

4'-Methyl-4-(phenylethynyl)biphenyl (9): Off-white solid, mp $155-156{ }^{\circ} \mathrm{C}$ (Lit. ${ }^{34} \mathrm{mp} .155{ }^{\circ} \mathrm{C}$ ); IR $\left(v_{\max }, \mathrm{cm}^{-1}\right): 3025,2915,2208,1492 .{ }^{1} \mathrm{H}$ NMR $\left(400 \mathrm{MHz}, \mathrm{CDCl}_{3}\right): \delta_{\mathrm{H}} 2.39\left(3 \mathrm{H}, \mathrm{s}, \mathrm{CH}_{3}\right), 7.24$ $\left(2 \mathrm{H}_{\text {arom }}, \mathrm{d},{ }^{3} J_{\mathrm{HH}} 8.0 \mathrm{~Hz}, 2 \mathrm{CH}\right), 7.33-7.37\left(3 \mathrm{H}_{\text {arom }}, \mathrm{m}, 3 \mathrm{CH}\right), 7.50\left(2 \mathrm{H}_{\text {arom }}, \mathrm{d},{ }^{3} J_{\mathrm{HH}} 8.0 \mathrm{~Hz}, 2 \mathrm{CH}\right)$, 7.54-7.60 $\left(6 \mathrm{H}_{\text {arom }}, \mathrm{m}, 6 \mathrm{CH}\right) ;{ }^{13} \mathrm{C} \mathrm{NMR}\left(100 \mathrm{MHz}, \mathrm{CDCl}_{3}\right): \delta_{\mathrm{C}} 21.1,89.4,89.9,121.8,123.3$, $126.5,126.8,128.3,129.6,131.6,131.9,132.3,137.4,137.5,140.9$; MS (EI, $70 \mathrm{eV}): \mathrm{m} / \mathrm{z}(\%)=$ $269\left(\mathrm{M}^{+}+1,37.5\right), 268\left(\mathrm{M}^{+}, 100\right), 251$ (10.2), 189 (15.6), 150 (5.4), 115 (11.1), 106 (9.3), 91 (5.6), 77 (6.9), 63 (13.6), 51 (17.9).

3'-Methoxy-4-(phenylethynyl)biphenyl (10): White crystals, mp $106^{\circ} \mathrm{C}$; IR $\left(v_{\max }, \mathrm{cm}^{-1}\right)$ : 3012, 2926, 2206, 1591. ${ }^{1} \mathrm{H}$ NMR $\left(400 \mathrm{MHz}, \mathrm{CDCl}_{3}\right): \delta_{\mathrm{H}} 3.87\left(3 \mathrm{H}, \mathrm{s}, \mathrm{CH}_{3}\right), 6.90-6.92\left(1 \mathrm{H}_{\text {arom }}, \mathrm{m}\right.$, $1 \mathrm{CH}), 7.13-7.39\left(5 \mathrm{H}_{\text {arom }}, \mathrm{m}, 5 \mathrm{CH}\right), 7.54-7.62\left(7 \mathrm{H}_{\text {arom }}, \mathrm{m}, 7 \mathrm{CH}\right) ;{ }^{13} \mathrm{C} \mathrm{NMR}\left(100 \mathrm{MHz}, \mathrm{CDCl}_{3}\right): \delta_{\mathrm{C}}$ $55.3,89.2,90.1,112.7,113.0,119.5,122.3,123.2,127.0,128.2,128.3,129.9,131.6,131.9$, 140.8, 141.8, 159.9; MS (EI, $70 \mathrm{eV}): m / z(\%)=284(100)\left[\mathrm{M}^{+}\right], 254(7.5), 241(20.5), 215$ (4.5), 142 (6.3), 126 (5.5), 108 (6.8). Anal. Calcd for $\mathrm{C}_{21} \mathrm{H}_{16} \mathrm{O}$ (284.35): C, 88.70; H, 5.67\%. Found: C, 88.98; H, $5.47 \%$.

3-(4-(Phenylethynyl)phenyl)thiophene (11): Off-white solid, $\mathrm{mp} 175-176{ }^{\circ} \mathrm{C}$; IR $\left(v_{\max }, \mathrm{cm}^{-1}\right)$ : 3096, 2213, 1589, 1435. ${ }^{1} \mathrm{H}$ NMR $\left(400 \mathrm{MHz}, \mathrm{CDCl}_{3}\right): \delta_{\mathrm{H}} 7.20\left(1 \mathrm{H}_{\text {thiophene, }} \mathrm{s}, 1 \mathrm{CH}\right), 7.34-7.41$ $\left(5 \mathrm{H}_{\text {arom }}, \mathrm{m}, 5 \mathrm{CH}\right), 7.49-7.60\left(6 \mathrm{H}_{\text {arom }}, \mathrm{m}, 6 \mathrm{CH}\right) ;{ }^{13} \mathrm{C} \mathrm{NMR}\left(100 \mathrm{MHz}, \mathrm{CDCl}_{3}\right): \delta_{\mathrm{C}} 89.3,89.9$, $120.8,121.8,123.2,126.1,126.3,126.5,128.2,128.4,131.6,132.1,135.5,141.6$; MS (EI, 70 $\mathrm{eV}): m / z(\%)=260(3.1)\left[\mathrm{M}^{+}\right], 230(53.7), 215$ (89.7), 201 (16.7), 165 (16.5), 152 (64.9), 125 (20.4), 80 (85.4), 64 (100), 55 (55.6). Anal. Calcd for $\mathrm{C}_{18} \mathrm{H}_{12} \mathrm{~S}$ (260.35): C, 83.04; H, 4.65; S, $12.32 \%$. Found: C, $82.76 ; \mathrm{H}, 4.55 ; \mathrm{S}, 12.28 \%$.

4-(1-Octynyl)biphenyl (12): ${ }^{35}$ Yellow oil; IR $\left(v_{\max }, \mathrm{cm}^{-1}\right)$ : 3058, 2926, 2219, 1479. ${ }^{1} \mathrm{H}$ NMR $\left(300 \mathrm{MHz}, \mathrm{CDCl}_{3}\right): \delta_{\mathrm{H}} 0.90\left(3 \mathrm{H}_{\text {aliph }}, \mathrm{t},{ }^{3} J_{\mathrm{HH}} 5.7 \mathrm{~Hz}, \mathrm{CH}_{3}\right), 1.25-1.64\left(8 \mathrm{H}_{\mathrm{aliph}}, \mathrm{m}, 4 \mathrm{CH}_{2}\right), 2.41$ $\left(2 \mathrm{H}_{\text {aliph }}, \mathrm{t},{ }^{3} \mathrm{~J}_{\mathrm{HH}} 7.2 \mathrm{~Hz}, \mathrm{CH}_{2}\right), 7.31-7.55\left(9 \mathrm{H}_{\text {arom }}, \mathrm{m}, 9 \mathrm{CH}\right)$; MS (EI, $\left.70 \mathrm{eV}\right): \mathrm{m} / z(\%)=262\left(\mathrm{M}^{+}\right.$, 72.4), 240 (68.9), 231 (74.7), 215 (94.3), 191 (100), 180 (37.9), 137 (42.5), 121 (42.5), 98 (68.9), $86(40.2), 62$ (85.1), 52 (36.8).

4-(1-Octynyl)-3'-chloro-1,1'-biphenyl (13): Colorless oil; IR ( $\left.v_{\max }, \mathrm{cm}^{-1}\right)$ : 3027, 2925, 2222, 1644, 1494. ${ }^{1} \mathrm{H}$ NMR $\left(300 \mathrm{MHz}, \mathrm{CDCl}_{3}\right): \delta_{\mathrm{H}} 0.91\left(3 \mathrm{H}_{\text {aliph }}, \mathrm{t},{ }^{3} J_{\mathrm{HH}} 7.0 \mathrm{~Hz}, \mathrm{CH}_{3}\right), 1.23-1.65$ $\left(8 \mathrm{H}_{\text {aliph }}, \mathrm{m}, 4 \mathrm{CH}_{2}\right), 2.42\left(2 \mathrm{H}_{\text {aliph }}, \mathrm{t},{ }^{3} J_{\mathrm{HH}} 7.2 \mathrm{~Hz}, \mathrm{CH}_{2}\right), 7.29-7.55\left(8 \mathrm{H}_{\text {arom }}, \mathrm{m}, 8 \mathrm{CH}\right), 7.62\left(1 \mathrm{H}_{\text {arom, }}\right.$, $\left.\mathrm{d},{ }^{4} J_{\mathrm{HH}} 8.4 \mathrm{~Hz}, \mathrm{CH}\right) ;{ }^{13} \mathrm{C}$ NMR $\left(100 \mathrm{MHz}, \mathrm{CDCl}_{3}\right): \delta_{\mathrm{C}} 14.1,19.5,22.6,28.6,28.7,31.3,80.2$, $91.7,123.7,125.1,127.1,127.3,127.5,129.9,132.0,134.7,138.6,142.3$; MS (EI, $70 \mathrm{eV}): \mathrm{m} / \mathrm{z}$ 
$(\%)=299\left(\mathrm{M}^{+}+2,52.1\right), 297\left(\mathrm{M}^{+}, 100\right), 288$ (52.4), 267 (14.5), 253 39.9), 230 (89.2), 215 (76.8), 202 (38.8), 189 (72.9), 152 (76.5), 113 (43.9), 101 (19.1), 80 (27.3), 64 (21.2). Anal. Calcd for $\mathrm{C}_{20} \mathrm{H}_{21} \mathrm{Cl}$ (296.83): C, 80.93; H, 7.13\%. Found: $\mathrm{C}, 80.78 ; \mathrm{H}, 7.20 \%$.

4-(1-Octynyl)-4'-methyl-1,1'-biphenyl (14): Off-white solid, mp 36-37 ${ }^{\circ} \mathrm{C}$; IR $\left(v_{\max }, \mathrm{cm}^{-1}\right)$ : 3026, 2924, 2223, 1494. ${ }^{1} \mathrm{H}$ NMR $\left(300 \mathrm{MHz}, \mathrm{CDCl}_{3}\right): \delta_{\mathrm{H}} 0.91\left(3 \mathrm{H}_{\mathrm{aliph}}, \mathrm{t},{ }^{3} J_{\mathrm{HH}} 7.0 \mathrm{~Hz}, \mathrm{CH}_{3}\right)$, 1.25-1.65 ( $\left.8 \mathrm{H}_{\text {aliph }}, \mathrm{m}, 4 \mathrm{CH}_{2}\right), 2.38\left(3 \mathrm{H}_{\text {aliph }}, \mathrm{s}, \mathrm{CH}_{3}\right), 2.42\left(2 \mathrm{H}_{\text {aliph }}, \mathrm{t},{ }^{3} J_{\mathrm{HH}} 7.2 \mathrm{~Hz}, \mathrm{CH}_{2}\right), 7.23-7.25$ $\left(2 \mathrm{H}_{\text {arom }}, \mathrm{d},{ }^{3} \mathrm{~J}_{\mathrm{HH}} 8.4 \mathrm{~Hz}, 2 \mathrm{CH}\right), 7.43-7.64\left(6 \mathrm{H}_{\text {arom }}, \mathrm{m}, 6 \mathrm{CH}\right) ;{ }^{13} \mathrm{C} \mathrm{NMR}\left(100 \mathrm{MHz}, \mathrm{CDCl}_{3}\right): \delta_{\mathrm{C}}$ $14.1,19.5,21.1,22.6,28.6,28.7,31.4,80.4,91.0,122.7,126.6,126.8,129.5,131.9,137.3$, 137.6, 140.1; MS (EI, $70 \mathrm{eV}): m / z(\%)=277\left(\mathrm{M}^{+}+1,23.6\right), 276\left(\mathrm{M}^{+}, 100\right), 247$ (12.6), 233 (28.9), 219 (27.9), 205 (81.3), 192 (42.3), 179 (21.9), 165 (16.9), 115 (17.6), 105 (25.9), 91 (20.4), 79 (15.1), 57 (24.3), 55 (30.0). Anal. Calcd for $\mathrm{C}_{21} \mathrm{H}_{24}$ (276.41): C, 91.25; H, 8.75\%. Found: C, 91.11; H, 8.64\%.

4-(1-Octynyl)-3'-methoxy-1,1'-biphenyl (15): Colorless oil; IR $\left(v_{\max }, \mathrm{cm}^{-1}\right)$ : 3037, 2926, 2224, 1459. ${ }^{1} \mathrm{H}$ NMR $\left(400 \mathrm{MHz}, \mathrm{CDCl}_{3}\right): \delta_{\mathrm{H}} 0.91\left(3 \mathrm{H}_{\text {aliph }}, \mathrm{t},{ }^{3} J_{\mathrm{HH}} 7.2 \mathrm{~Hz}, \mathrm{CH}_{3}\right), 1.15-1.34\left(4 \mathrm{H}_{\mathrm{aliph}}, \mathrm{m}\right.$, 2 $\left.\mathrm{CH}_{2}\right), 1.42-1.49\left(2 \mathrm{H}_{\text {aliph }}, \mathrm{m}, \mathrm{CH}_{2}\right), 1.57-1.64\left(2 \mathrm{H}_{\text {aliph }}, \mathrm{m}, \mathrm{CH}_{2}\right), 2.41\left(2 \mathrm{H}, \mathrm{t},{ }^{3} J_{\mathrm{HH}} 7.2 \mathrm{~Hz}, \mathrm{CH}_{2}\right)$, $3.83\left(3 \mathrm{H}_{\text {aliph }}, \mathrm{s}, \mathrm{OCH}_{3}\right), 6.86-6.88\left(1 \mathrm{H}_{\text {arom }}, \mathrm{m}, \mathrm{CH}\right), 7.09-9.21\left(2 \mathrm{H}_{\text {arom }}, \mathrm{m}, 2 \mathrm{CH}\right), 7.31-7.34$ $\left(1 \mathrm{H}_{\text {arom }}, \mathrm{m}, \mathrm{CH}\right), 7.44\left(2 \mathrm{H}_{\text {arom }}, \mathrm{d},{ }^{3} \mathrm{~J}_{\mathrm{HH}} 8.4 \mathrm{~Hz}, 2 \mathrm{CH}\right), 7.50\left(2 \mathrm{H}_{\text {arom }}, \mathrm{d},{ }^{3} J_{\mathrm{HH}} 8.4 \mathrm{~Hz}, 2 \mathrm{CH}\right) ;{ }^{13} \mathrm{C}$ NMR $\left(100 \mathrm{MHz}, \mathrm{CDCl}_{3}\right): \delta_{\mathrm{C}} 14.1,19.5,22.6,28.7,29.7,31.4,55.2,80.3,91.2,112.8,119.4$, $123.2,126.9,127.1,129.7,131.9,139.9,141.9,159.9$; MS (EI, $70 \mathrm{eV}): \mathrm{m} / z(\%)=292\left(\mathrm{M}^{+}\right.$, 20.6), 291 (31.1), 270 (29.7), 255 (46.9), 248 (31.6), 220 (27.3), 207 (33.5), 190 (30.1), 145 (35.4), 138 (100), 102 (12.9), 90 (16.7), 76 (17.7), 63 (18.7). Anal. Calcd for $\mathrm{C}_{21} \mathrm{H}_{24} \mathrm{O}(292.41)$ : C, 86.26; H, 8.27\%. Found: C, 86.49; H, 8.24\%.

3-(4-(1-Octynyl)phenyl)thiophene (16): Off-white solid, mp $35^{\circ} \mathrm{C}$; IR $\left(v_{\max }, \mathrm{cm}^{-1}\right)$ : 3100, 2925, 2225, 1458. ${ }^{1} \mathrm{H}$ NMR $\left(400 \mathrm{MHz}, \mathrm{CDCl}_{3}\right): \delta_{\mathrm{H}} 0.91\left(3 \mathrm{H}_{\text {aliph }}, \mathrm{t},{ }^{3} J_{\mathrm{HH}} 7.2 \mathrm{~Hz}, \mathrm{CH}_{3}\right), 1.25-1.34$ $\left(4 \mathrm{H}_{\text {aliph }}, \mathrm{m}, 2 \mathrm{CH}_{2}\right), 1.42-1.49\left(2 \mathrm{H}_{\text {aliph }}, \mathrm{m}, \mathrm{CH}_{2}\right), 1.55-1.64\left(2 \mathrm{H}_{\text {aliph }}, \mathrm{m}, \mathrm{CH}_{2}\right), 2.41\left(2 \mathrm{H}_{\text {aliph }}, \mathrm{t},{ }^{3} J_{\mathrm{HH}}\right.$ $\left.7.4 \mathrm{~Hz}, \mathrm{CH}_{2}\right), 6.31-7.52\left(7 \mathrm{H}_{\text {arom+thiophene, }} \mathrm{m}, 7 \mathrm{CH}\right) ;{ }^{13} \mathrm{C} \mathrm{NMR}\left(100 \mathrm{MHz}, \mathrm{CDCl}_{3}\right): \delta_{\mathrm{C}} 14.1,19.5$, 22.6, 28.6, 28.7, 31.4, 80.4, 91.1, 120.5, 122.7, 126.1, 126.3, 126.8, 131.9, 134.7, 141.7; MS (EI, $70 \mathrm{eV}): m / z(\%)=269\left(\mathrm{M}^{+}+1,22.1\right), 268\left(\mathrm{M}^{+}, 100\right), 239(15.4), 225(42.8), 211$ (32.7), 197 (81.4), 184 (21.3), 165 (45.4), 152 (25.5), 139 (12.6), 115 (19.3), 97 (11.7), 79 (7.6), 63 (11.2). Anal. Calcd for $\mathrm{C}_{18} \mathrm{H}_{20} \mathrm{~S}$ (268.41): C, 80.54; H, 7.51; S, 11.95\%. Found: C, 80.27; H, 7.33; S, $11.82 \%$.

\section{Preparation of 4-bromo-1-(4-hexyloxyphenylethynyl)benzene (18): ${ }^{39}$}

To a stirred mixture of $\mathrm{PdCl}_{2}\left(\mathrm{PPh}_{3}\right)_{2}(7 \mathrm{mg}, 0.01 \mathrm{mmol}), \mathrm{CuI}(3.8 \mathrm{mg}, 0.02 \mathrm{mmol})$ and 1-bromo4-iodobenzene 3 (283 mg, $1 \mathrm{mmol})$ in toluene $(1 \mathrm{~mL})$ and $\mathrm{Et}_{3} \mathrm{~N}(280 \mu \mathrm{L}, 2 \mathrm{mmoles})$ in water (1 $\mathrm{mL}$ ), was added 4-hexyloxyphenylacetylene $17(242 \mathrm{mg}, 1.2 \mathrm{mmol})$ under an argon atmosphere. The stirring was continued at room temperature for $10 \mathrm{~h}$. The two phases of the resulting mixture were separated and the aqueous layer was extracted with diethyl ether. The combined organic layer was concentrated under reduced pressure to leave a crude solid, which was purified by flash column chromatography on silica gel using hexane/ethyl acetate (15:1) to give $0.32 \mathrm{~g}$ 
compound 18 (90\% yield) as white crystals. Mp. $108-109^{\circ} \mathrm{C}$; IR $\left(v_{\max }, \mathrm{cm}^{-1}\right): 3050,2925,2855$, 2206, 1598, 1507. ${ }^{1} \mathrm{H}$ NMR $\left(300 \mathrm{MHz}, \mathrm{CDCl}_{3}\right): \delta_{\mathrm{H}} 0.93\left(3 \mathrm{H}_{\text {aliph }}, \mathrm{t},{ }^{3} J_{\mathrm{HH}} 6.9 \mathrm{~Hz}, \mathrm{CH}_{3}\right), 1.34-1.54$ $\left(6 \mathrm{H}_{\text {aliph }}, \mathrm{m}, 3 \mathrm{CH}_{2}\right), 1.78-1.83\left(2 \mathrm{H}_{\text {aliph }}, \mathrm{m}, \mathrm{CH}_{2}\right), 3.98\left(2 \mathrm{H}_{\text {aliph }}, \mathrm{t},{ }^{3} J_{\mathrm{HH}} 6.6 \mathrm{~Hz}, \mathrm{OCH}_{2}\right), 6.88\left(2 \mathrm{H}_{\text {arom }}\right.$, $\left.\mathrm{d},{ }^{3} J_{\mathrm{HH}} 8.7 \mathrm{~Hz}, 2 \mathrm{CH}\right), 7.37\left(2 \mathrm{H}_{\text {arom }}, \mathrm{d},{ }^{3} J_{\mathrm{HH}} 8.7 \mathrm{~Hz}, 2 \mathrm{CH}\right), 7.43-7.49\left(4 \mathrm{H}_{\text {arom }}, \mathrm{m}, 4 \mathrm{CH}\right)$; MS (EI, $70 \mathrm{eV}): m / z(\%)=358\left(\mathrm{M}^{+}+2,48.7\right), 357\left(\mathrm{M}^{+}+1,13.5\right), 356\left(\mathrm{M}^{+}, 49.5\right), 274(98.2), 272(100)$, 205 (25.7), 163 (27.7), 121 (28.3), 55 (10.4).

\section{Synthesis of asymmetric 1,4-diethynylbenzene derivatives 19 and 20}

To a stirred mixture of $\mathrm{PdCl}_{2}\left(\mathrm{PPh}_{3}\right)_{2}(3.5 \mathrm{mg}, 0.005 \mathrm{mmol})$, $\mathrm{CuI}(1.9 \mathrm{mg}, 0.01 \mathrm{mmol})$ and 4bromo-1-(oct-1-ynyl)benzene $5(132 \mathrm{mg}, 0.5 \mathrm{mmol})$ in toluene $(1 \mathrm{~mL})$ and $\mathrm{Et}_{3} \mathrm{~N}(280 \mu \mathrm{L}, 2$ $\mathrm{mmol})$ in water $(1 \mathrm{~mL})$, was added phenylacetylene 1 or 4-hexyloxyphenylacetylene 17 (0.6 mmol) dropwise under an argon atmosphere. The stirring was continued for $24 \mathrm{~h}$ at $60{ }^{\circ} \mathrm{C}$. The two phases of the resulting mixture were separated and the aqueous layer was extracted with diethyl ether. The combined organic layer was concentrated under reduced pressure to leave a crude solid, which was purified by flash column chromatography on silica gel using hexane/ethyl acetate (10:1) to give the corresponding coupling products $\mathbf{1 9}$ and $\mathbf{2 0}$, respectively.

1-(1-Octynyl)-4-(2-phenylethynyl)benzene (19): Off-white solid, mp. 60-61 ${ }^{\circ} \mathrm{C}$; IR $\left(v_{\max }, \mathrm{cm}^{-1}\right)$ : 3009, 2927, 2858, 2214, 1601, 1513. ${ }^{1} \mathrm{H}$ NMR $\left(300 \mathrm{MHz}, \mathrm{CDCl}_{3}\right): \delta_{\mathrm{H}} 0.94\left(3 \mathrm{H}_{\mathrm{aliph}}, \mathrm{t},{ }^{3} J_{\mathrm{HH}} 6.9\right.$ $\left.\mathrm{Hz}, \mathrm{CH}_{3}\right), 1.29-1.36\left(4 \mathrm{H}_{\text {aliph }}, \mathrm{m}, 2 \mathrm{CH}_{2}\right), 1.43-1.53\left(2 \mathrm{H}_{\text {aliph }}, \mathrm{m}, \mathrm{CH}_{2}\right), 1.59-1.66\left(2 \mathrm{H}_{\text {aliph }}, \mathrm{m}, \mathrm{CH}_{2}\right)$, $2.44\left(2 \mathrm{H}_{\text {aliph }}, \mathrm{t},{ }^{3} \mathrm{~J}_{\mathrm{HH}} 6.9 \mathrm{~Hz}, \mathrm{CH}_{2}\right), 7.35-7.45\left(3 \mathrm{H}_{\text {arom }}, \mathrm{m}, 3 \mathrm{CH}\right), 7.48-7.56\left(6 \mathrm{H}_{\text {arom }}, \mathrm{m}, 6 \mathrm{CH}\right) ;{ }^{13} \mathrm{C}$ NMR $\left(75 \mathrm{MHz}, \mathrm{CDCl}_{3}\right): \delta_{\mathrm{C}} 13.9,19.4,22.5,25.6,28.6,31.3,80.3,87.7,90.8,92.2,114.5$, $114.9,122.6,123.4,123.6,131.1,131.3,132.9$; MS (EI, $70 \mathrm{eV}): m / z(\%)=287\left(\mathrm{M}^{+}, 3.5\right), 231$ (6.8), 205 (58.6), 121 (46.6), 80 (100), 64 (59.6), 55 (14.8). Anal. Calcd for $\mathrm{C}_{22} \mathrm{H}_{22}$ (286.41): C, 92.26; H, 7.74\%. Found: C, 92.45; H, 7.87\%.

1-(4-Hexyloxyphenylethynyl)-4-(1-octynyl)benzene (20): Off-white solid, mp. 73-74 ${ }^{\circ} \mathrm{C}$; IR $\left(v_{\max }, \mathrm{cm}^{-1}\right): 3040,2925,2853,2214,1601,1511 .{ }^{1} \mathrm{H} \mathrm{NMR}\left(300 \mathrm{MHz}, \mathrm{CDCl}_{3}\right): \delta_{\mathrm{H}} 0.91-0.96$ $\left(6 \mathrm{H}_{\text {aliph }}, \mathrm{m}, 2 \mathrm{CH}_{3}\right), 1.29-1.51\left(16 \mathrm{H}_{\text {aliph }}, \mathrm{m}, 8 \mathrm{CH}_{2}\right), 2.44\left(2 \mathrm{H}_{\text {aliph }}, \mathrm{t},{ }^{3} J_{\mathrm{HH}} 6.9 \mathrm{~Hz}, \mathrm{CH}_{2}\right), 3.98$ $\left(2 \mathrm{H}_{\text {aliph }}, \mathrm{t},{ }^{3} \mathrm{~J}_{\mathrm{HH}} 6.9 \mathrm{~Hz}, \mathrm{OCH}_{2}\right), 6.86\left(2 \mathrm{H}_{\text {arom }}, \mathrm{d},{ }^{3} \mathrm{~J}_{\mathrm{HH}} 8.4 \mathrm{~Hz}, 2 \mathrm{CH}\right), 7.38-7.47\left(6 \mathrm{H}_{\text {arom }}, \mathrm{m}, 6 \mathrm{CH}\right)$; ${ }^{13} \mathrm{C}$ NMR $\left(75 \mathrm{MHz}, \mathrm{CDCl}_{3}\right): \delta_{\mathrm{C}} 13.00,13.02,18.36,21.42,21.45,24.56,27.45,27.53,28.02$, 30.20, 30.43, 66.97, 79.28, 86.72, 90.04, 91.52, 113.59, 121.51, 122.63, 130.08, 130.37, 131.65, 131.90, 158.30. Anal. Calcd for $\mathrm{C}_{28} \mathrm{H}_{34} \mathrm{O}$ (386.57): C, 87.00; H, 8.87\%. Found: C, 86.83; H, $8.96 \%$.

\section{Alternative synthesis of 1-(4-hexyloxyphenylethynyl)-4-(1-octynyl)benzene (20)}

To a mixture of $\mathrm{PdCl}_{2}\left(\mathrm{PPh}_{3}\right)_{2}(3.5 \mathrm{mg}, 0.005 \mathrm{mmol})$, CuI (1.9 mg, $\left.0.01 \mathrm{mmol}\right)$, and 4-bromo-1(4-hexyloxyphenylethynyl)benzene $18(178 \mathrm{mg}, 0.5 \mathrm{mmol})$ in toluene $(1 \mathrm{~mL})$ and $\mathrm{Et}_{3} \mathrm{~N}(140 \mu \mathrm{L}$, $1 \mathrm{mmol})$ in water $(1 \mathrm{~mL})$, was added 1-octyne $2(90 \mu \mathrm{L}, 0.6 \mathrm{mmol})$ dropwise under an argon atmosphere. The crude product was purified as shown above to give $0.19 \mathrm{~g}(98 \%$ yield $)$ of $\mathbf{2 0}$. 


\section{References}

1. Sonogashira, K. In Metal-Catalyzed Cross-Coupling Reactions; Diedrich, F., de Meijere, A., eds.; Wiley-VCH: Weinheim, 2004; vol. 1, pp 319.

2. Chinchilla, R.; N'ajera, C. Chem. Soc. Rev., 2011, 40, 5084.

http://dx.doi.org/10.1039/c1cs15071e

3. Yu, S.; Haight, A.; Kotecki, B.; Wang, L.; Lukin, K.; Hill, D. R. J. Org. Chem., 2009, 74, 9539.

http://dx.doi.org/10.1021/jo901943s

4. Berliner, M. A.; Cordi, E. M.; Dunetz, J. R.; Price, K. E. Org. Process. Res. Dev., 2010, 14, 180.

http://dx.doi.org/10.1021/op900263b

5. Liu, J. Z.; Lam, J. W. Y.; Tang, B. Z. Chem. Rev., 2009, 109, 5799.

http://dx.doi.org/10.1021/cr900149d

6. Chinchilla, R.; Najera, C. Chem. Rev., 2007, 107, 874. http://dx.doi.org/10.1021/cr050992x

7. Altenburger, J. M.; Lassalle, G. Y.; Matrougui, M.; Galtier, D.; Jetha, J. C.; Bocskei, Z.; Berry, C. N.; Lunven, C.; Lorrain, J.; Herault, J. P.; Schaeffer, P.; O’Connor, S. E.; Herbert, J. M. Bioorg. Med. Chem., 2004, 12, 1713.

http://dx.doi.org/10.1016/j.bmc.2004.01.016

8. Dai, W.-M.; Lai, K.-W.; Wu, A.; Hamaguchi, W.; Lee, M. Y. H.; Zhou, L.; Ishii, A.; Nishimoto, S. J. Med. Chem., 2002, 45, 758.

http://dx.doi.org/10.1021/jm015588e

9. Suzuki, A. Angew. Chem. Int. Ed., 2011, 50, 6723.

10. Alonso, F., Beletskaya, I. P., Yus, M. Tetrahedron, 2008, 64, 3047. http://dx.doi.org/10.1016/j.tet.2007.12.036

11. Kelly, T. R.; Fu, Y.; Sieglen, J. T.; de Silva, H. Org. Lett., 2000, 2, 2351. http://dx.doi.org/10.1021/o1006127a

12. Jeong, S. J.; Higuchi, R.; Miyamoto, T.; Ono, M.; Kuwano, M.; Mawatari, S. F. J. Nat. Prod., 2002, 65, 1344.

http://dx.doi.org/10.1021/np010577+

13. Ankita, C.; Jha, K.; Sachin, K. J. Adv. Sci., 2012, 3, 3.

14. Amatore, C.; Le Duc, G.; Jutand, A. Chem. Eur. J., 2013, 19, 10082.

http://dx.doi.org/10.1002/chem.201300177

15. Butler, R. N.; Coyne, A. G. Chem. Rev., 2010, 110, 6302.

http://dx.doi.org/10.1021/cr100162c

16. Chanda, A.; Fokin, V. V. Chem. Rev., 2009, 109, 725. http://dx.doi.org/10.1021/cr800448q

17. Chinchilla, R.; Na'jera, C.; Chem. Rev., 2007, 107, 874. http://dx.doi.org/10.1021/cr050992x 
18. Dupont, J.; Consorti, C. S.; Spencer, J. Chem. Rev., 2005, 105, 2527.

http://dx.doi.org/10.1021/cr030681r

19. Dawood, K. M.; Kirschning, A. Tetrahedron, 2005, 61, 12121. http://dx.doi.org/10.1016/j.tet.2005.07.113

20. Solodenko, W.; Brochwitz, C.; Wartchow, R.; Hashem, Md. A.; Vaultier, M.; Dawood, K. M.; Kirschning, A. Mol. Div., 2005, 9, 333. http://dx.doi.org/10.1007/s11030-005-7457-y

21. Dawood, K. M.; Solodenko, W.; Kirschning, A. Arkivoc, 2007 (v), 104.

22. Dawood, K. M. Tetrahedron, 2007, 63, 9642. http://dx.doi.org/10.1016/j.tet.2007.07.029

23. Dawood, K. M.; Fayed, M. S.; Elkhalea, M. M. Arkivoc, 2009, (xiii), 324.

24. Shaaban, M. R.; Darweesh, A. F.; Dawood, K. M.; Farag, A. F. Arkivoc, 2010, (x), 208. http://dx.doi.org/10.3998/ark.5550190.0011.a18

25. Darweesh, A. F.; Shaaban, M. R.; Farag, A. F.; Metz, P.; Dawood, K. M., Synthesis, 2010, 3163.

26. Dawood, K. M.; El-Deftar, M. M. Arkivoc, 2010, (ix), 319. http://dx.doi.org/10.3998/ark.5550190.0011.930

27. Dawood, K. M.; El-Deftar, M. M. Synthesis, 2010, 1030. http://dx.doi.org/10.1055/s-0029-1218662

28. Dawood, K. M.; Farag, A. F.; El-Deftar, M. M. Gardinar, M.; Abdelaziz, H. A. Arkivoc, 2013, (iii), 210. http://dx.doi.org/10.3998/ark.5550190.0014.317

29. Dawood, K. M.; Hassaneen, H. M.; Abdelhadi, H. A., Ahmed, M. S. M., Mohamed, M. A.M. J. Braz. Chem. Soc., 2014, 25, 1688.

30. Hogben, H. J.; Sprafke, J. K.; Hoffmann, M.; Pawlicki, M.; Anderson, H. L. J. Am. Chem. Soc., 2011, 133, 20962. http://dx.doi.org/10.1021/ja209254r

31. Hiraoka, S.; Harano, K.; Shiro, M.; Shionoya, M. J. Am. Chem. Soc., 2008, 130, 14368. http://dx.doi.org/10.1021/ja804885k

32. Muroga, T.; Sakaguchi, T.; Hashimoto, T. Polymer, 2012, 53, 4380. http://dx.doi.org/10.1016/j.polymer.2012.08.009

33. Chow, H. -F.; Wan, C.-W.; Low, K.-H. Yeung, Y. -Y. J. Org. Chem., 2001, 66, 1910. http://dx.doi.org/10.1021/jo001538q

34. Kim, D.-S.; Ham, J. Org. Lett., 2010, 12, 1092. http://dx.doi.org/10.1021/ol100081v

35. Zhao, J.; Yu, Y.; Ma, S. Chem. Eur. J., 2010, 16, 74. http://dx.doi.org/10.1002/chem.200901287

36. Juang, T. M.; Chen, Y. N.; Lung, S. H.; Lu, Y. H.; Hsu, C. S.; Wu, S. T.; Liq. Cryst., 1993, $15,529$. http://dx.doi.org/10.1080/02678299308036472 
37. Liang, B.; Dai, M.; Chen, J.; Yang, Z. J. Org. Chem., 2005, 70, 391.

http://dx.doi.org/10.1021/jo048599z

38. Lucas, N. T.; Notaras, E. G. A.; Petrie, S.; Stranger, R.; Humphrey, M. G. Organometallic, 2003, 22, 708 .

http://dx.doi.org/10.1021/om020910k

39. Kondo, K.; Fujitani, T.; Ohnishi, N., J. Mater. Chem., 1997, 7, 429.

http://dx.doi.org/10.1039/a606915k 